Pacheco, R.T.B. Planejamento de lazer e conservação ambiental num grande centro urbano: Parques Naturais Municipais de São Paulo. Anais do VIII Congresso Nacional de Ecoturismo e do IV Encontro Interdisciplinar de Ecoturismo em Unidades de Conservação. Revista Brasileira de Ecoturismo, São Paulo, v.4, n.4, 2011, p. 587.

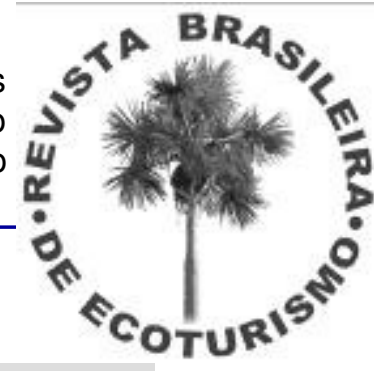

\title{
PLANEJAMENTO DE LAZER E CONSERVAÇÃO AMBIENTAL NUM GRANDE CENTRO URBANO: PARQUES NATURAIS MUNICIPAIS DE SÃO PAULO
}

\author{
Reinaldo Tadeu Boscolo Pacheco* \\ *Escola de Artes, Ciências e Humanidades - USP \\ E-mail: repacheco@usp.br
}

As atividades de lazer, turismo, educação ambiental e recreação em áreas protegidas para a população de seu entorno e também para visitantes advindos de outras regiões se inserem em um programa de gestão denominado Programa de Uso Público. O presente artigo apresenta os principais aspectos do planejamento do Uso Público em quatro novos Parques Naturais Municipais que estão em processo de criação, no município de São Paulo, a saber: Parque Natural Municipal de Bororé, da Varginha, do Itaim e do Jaceguava. Dá-se destaque no presente trabalho aos dois primeiros parques - Bororé e Varginha. Produto de compensação ambiental, essas novas Unidades de Conservação (UCs) estão inseridas em uma região caracterizada pela escassez de serviços públicos básicos, como saúde, educação, transporte, lazer, cultura e esporte. Desta forma, serão objeto de grande pressão por uso público. A partir da observação, embasada na teoria da interpretação das culturas, e também de entrevistas semi-estruturada com atores-chave das comunidades do entorno das novas UCs, pôde-se identificar as principais práticas de lazer e turismo dos moradores da região, assim como as dificuldades encontradas para que possam desfrutar seu tempo livre. Nesse sentido, o objetivo do trabalho é compatibilizar as aspirações de lazer das comunidades com as ações de conservação ambiental dos parques. Dentre os principais resultados, identificou-se que os principais espaços demandados pela população são: ciclovias, campo de futebol, locais para caminhar com segurança e espaços recreativos infantis. Com isso, compatibilizar as aspirações de lazer das comunidades com as ações de conservação ambiental dos parques torna-se o principal desafio da gestão do Uso Público dessas novas UCs.

Palavras-chave: Parques Naturais Municipais; São Paulo. Lazer. 